\title{
Seroprevalence Canine Survey for Selected Vector- Borne Pathogens of and Its Relationship with Poverty in Metropolitan Pereira, Colombia, 2020
}

\section{Katterine Bonilla-Aldana}

Fundacion Universitaria Autonoma de las Americas

Erwin J. Gutiérrez-Grajales

Fundacion Universitaria Autonoma de las Americas

\section{J. Paola Martínez-Arboleda}

Fundacion Universitaria Autonoma de las Americas

\section{María Angelica Reina-Mora}

Fundacion Universitaria Autonoma de las Americas

Adrián E. Trejos-Mendoza

Fundacion Universitaria Autonoma de las Americas

\section{Soffia Pérez-Vargas}

Fundacion Universitaria Autonoma de las Americas

\section{Lorenzo Valencia-Mejía}

Fundacion Universitaria Autonoma de las Americas

\section{Luisa F. Marín-Arboleda}

Fundacion Universitaria Autonoma de las Americas

\section{Daniela Osorio-Navia}

Fundacion Universitaria Autonoma de las Americas

Mariana Chacón-Peña

Fundacion Universitaria Autonoma de las Americas

\section{Luz Victoria González-Colonia}

Fundacion Universitaria Autonoma de las Americas

Jaime A. Cardona-Ospina

Fundacion Universitaria Autonoma de las Americas

\section{Erika Vanessa Jiménez-Posada}

Fundacion Universitaria Autonoma de las Americas

\section{Andrés Diaz}

Universidad Alexander Von Humboldt

\section{Jean Carlos Salazar}

Universidad Alexander Von Humboldt

\section{Manuel Sierra}


Universidad Nacional Autonoma de Honduras

\section{Fausto Muñoz}

Universidad Nacional Autonoma de Honduras

\section{Lysien I. Zambrano}

Universidad Nacional Autonoma de Honduras

\section{Eduardo Ramírez-Vallejo}

Fundacion Universitaria Autonoma de las Americas

\section{Juan Camilo Álvarez}

Universidad de Antioquia

Ingrid Lorena Jaramillo-Delgado

Universidad de Antioquia

\section{Samuel Pecho-Silva}

Universidad Cientifica del Sur

\section{Alberto Paniz-Mondolfi}

Icahn School of Medicine at Mount Sinai

\section{Álvaro A. Faccini-Martínez}

The University of Texas Medical Branch at Galveston

\section{Alfonso J. Rodriguez-Morales ( $\nabla$ alfonso.rodriguez@uam.edu.co )}

Fundacion Universitaria Autonoma de las Americas https://orcid.org/0000-0001-9773-2192

\section{Research Article}

Keywords: Anaplasma phagocytophilum, Anaplasma platys, Ehrlichia canis, Ehrlichia ewingii Dirofilaria immitis, tick-borne diseases, hemothropic pathogens, canine, zoonotic, Colombia.

Posted Date: June 1st, 2021

DOI: https://doi.org/10.21203/rs.3.rs-557962/v1

License: (c) (i) This work is licensed under a Creative Commons Attribution 4.0 International License. Read Full License 


\section{Abstract}

Background: Tick-borne diseases (TBD) and dirofilariasis are currently not under surveillance in most Latin American countries, and there is a significant lack of studies describing the current situation in most endemic areas, including Colombia. Seroprevalence studies are crucial for understanding the epidemiology of these vector-borne diseases.

Methods: A serosurvey for TBD and dirofilariasis amongst 100 dogs was carried out in the municipality of Pereira, located in the Coffee-Triangle region, Colombia. Samples were tested using a rapid assay test system (SNAP ${ }^{\circledR} 4 \mathrm{Dx} \circledast$ ); based on an enzyme immunoassay technique, screening for antibodies to Anaplasma phagocytophilum/platys (sensitivity 99.1\%), Borrelia burgdorferi s.l. (98.8\%), and Ehrlichia canis/ewingii (96.2\%) by using specific antigens, and checking for Dirofilaria immitis antigen based on specific antibodies (99.2\%). Bivariate analyses were performed on Stata ${ }^{\circledR} 14$, significant $p<0.05$.

Results: Global seroprevalence to the selected vector-borne pathogens was $74 \%$ (95\% Cl $65-83 \%)$. The highest seroprevalence was found for Ehrlichia canis/ewingii (74\%), followed by Anaplasma phagocytophilum/platys (16\%). Seropositivity for Borrelia spp. and Dirofilaria spp. was $0 \%$. All Anaplasma spp. seropositive dogs showed co-detection of Ehrlichia spp. (16\%). Seroprevalence was significantly higher among dogs from families of lower socioeconomic status / level (I, 86\%), followed by level II (74\%), and III (36\%) ( $p=0.001)$; no seropositive dogs were found in for levels IV and V (higher socioeconomic status). All dogs exhibiting anorexia (12\%) were invariably seropositive $(100 \%)(p=0.029)$. Seroprevalence was higher amongst those showing mucocutaneous paleness (95\%) compared to those without paleness $(68 \%)(p=0.013)(O R=9.3 ; 95 \% \mathrm{Cl} 1.18-72.9)$. There was high variability in seroprevalence through the studied areas, ranging from $0 \%$ (La Libertad Park) up to Combia, Cesar Nader, Las Brisas and Saturno localities $(100 \%)(p=0.033)$.

Conclusions: Given the high seroprevalence obtained in an area with documented presence of ticks, there is a potential risk for zoonotic transmission to humans. Further seroprevalence studies in humans are needed to assess the prevalence of infections. Poverty is highly associated with these tick-borne pathogens in Pereira, as shown in the present study.

\section{Background}

Tick-borne diseases (TBD) are an important group of infectious diseases that may affect both animals and humans, particularly in tropical and subtropical region of the world. Amongst these diseases are Lyme borreliosis, spotted fever group rickettsioses, Colorado tick fever, monocytic ehrlichiosis, tularemia, granulocytic anaplasmosis, amongst others [1-3].

Among the most vulnerable populations for these vector-borne diseases [4] are dogs [5-7]. Multiple studies worldwide have assessed the prevalence of such diseases in canine populations [8]. However, many countries still lack detailed studies, with many aspects in relation to their epidemiology that remain yet to be clarified, including many societal aspects [9-11]. 
Unfortunately, TBD, such as ehrlichiosis, anaplasmosis, and dirofilariasis, are not reportable and currently not under surveillance in most Latin American countries [12-17]. In addition, there is a significant gap of knowledge pertaining their circulation across endemic areas in certain countries, such as Colombia [1822]. This is why seroprevalence studies remain crucial to better understand the diverse epidemiological aspects of these vector-borne diseases.

Herein, we present a prospective study aimed to evaluate the seroprevalence of Anaplasma phagocytophilum/platys, Borrelia burgdorferi sensu lato (s.l.), Ehrlichia canis/ewingii, and Dirofilaria immitis infection and scrutinize on the main associated factors related to the epidemiology of tick-borne diseases amongst dogs inhabiting the municipality of Pereira, Risaralda department, Colombia, in 2020.

\section{Methods}

Pereira is the main city of the Coffee-Triangle region, which includes three departments (first administrative territory level) and 53 municipalities (second administrative territory level). Pereira is the capital of Risaralda ( 967,780 habitants in 2020), a department surrounded by six other western departments (Antioquia, Caldas, Tolima, Quindio, Valle del Cauca and Choco) [23]. Pereira's landscape embraces both urban and rural areas. The first consisting of 20 communities (the city) and the second by 12 corregiments (sub-municipalities) (both tertiary administrative territory level) (Fig. 1). As per the National Statistics Department (DANE, www.dane.gov.co) the total population for 2020 reached 477,027 inhabitants. The metropolitan area includes Dosquebradas and La Virginia municipalities (Fig. 1), with a reported 709,338 inhabitants for 2020. The communities of Rio Otun, Centro, San Joaquin, Del Café, Boston, El Oso, Consota and Cuba, are the most populated areas of the Pereira municipality, making up for $51 \%$ of its population (Fig. 2). The municipality of Pereira extends over an area of $702 \mathrm{Km}^{2}\left(4^{\circ} 48^{\prime} 51^{\prime \prime} \mathrm{N}\right.$ $75^{\circ} 41^{\prime} 40^{\prime \prime} \mathrm{W}$ ). The climate is tropical with an annual median temperature of $18.8^{\circ} \mathrm{C}$ (median minimum of $15.8^{\circ} \mathrm{C}$, median maximum of $26.3^{\circ} \mathrm{C}$ ).

Based on the municipality dog's census, we calculated a minimum sample of 98 dogs to be assessed. Finally, 100 were included distributed in four urban communes (out of 20) and four rural corregiments (out of 12) of the municipality Pereira, and its neighboring municipality of Dosquebradas (Fig. 1). From those owners who voluntarily accepted to participate with their dogs, only one dog was included, regardless of where co-living was in the same house.

Blood samples from each dog was individually collected from the radial vein into a sterile vacuum tube (Vacutainer, Becton, Dickinson and Company Franklin Lakes, NJ, USA) without anticoagulant at morning time. In the evening, samples were centrifuged at 1300-1800 $\times \mathrm{g}$ for $20 \mathrm{~min}$, followed by serum separation from the clot.

To determine selected-vector-borne pathogens exposure, a rapid enzyme-linked immunosorbent assay (ELISA) kit (SNAP® 4Dx® Plus Test Kit, IDEXX Laboratories, Inc, Westbrook, ME, USA) was used following the manufacturer's instructions [8]. This qualitative test allowed us to simultaneously detect the presence 
of circulating antibodies (IgG and IgM) against immunodominant proteins of E. canis/ewingii ( $\mathrm{p} 30$ and p30-1, sensitivity of $96.2 \%$ ), A. phagocytophilum/platys (p44/MSP2, sensitivity of $99.1 \%$ ), B. burgdorferi s.l. (C6, the sensitivity of $98.8 \%$ ), and $D$. immitis antigens (antigens principally produced by adult females) based on specific antibodies (sensitivity of $99.2 \%$ ). The SNAP® 4Dx® Plus Test Kit showed a specificity of $\sim 100 \%$ for the above mentioned microorganisms $[8,24,25]$. 4Dx® Plus Test Kit has been validated in dogs $[8,24,25]$.

Besides the general demographic, clinical and laboratory surveys, a questionnaire for social variables related to living conditions and households was also performed, including aspects such as: house vulnerability (defined according to five possible types of houses, from those with luxury and appropriate sanitary conditions to those without luxury and inappropriate sanitary conditions, last category considered as a vulnerable house); house location (in rural or urban areas); environmental elements close proximity to the house (e.g. small lakes, small rivers or wetlands); materials employed in the building of the walls (e.g. blocks, bricks, cement, wood, cardboard-tin) and the floors (e.g. cement, wood, soil); access to tap water; need of water collection and its keeping at appropriate receptacles; and disposal of sewage water and waste disposal (e.g. by an urban service) [26], among other social aspects such as the socioeconomic level of the house which is determined by the National Statistics Department (DANE).

Statistical analysis was performed using Stata 14®IC (Stata Corp., College Station, Texas, USA). Chisquare tests were used to compare proportions of positivity related to categorical dependent variables and establish statistical significance. Association between seropositivity and independent variables such as social house conditions, dog living conditions, and socioeconomic level was evaluated. For all the independent variables, chi-square $\left(\chi^{2}\right)$ and Fisher tests were used to assess associations and significance. In those significant values $(p<0.05)$, also the odds ratio with their $95 \%$ confidence interval $(95 \% \mathrm{Cl})$ was calculated.

The location of the houses hosting the dogs was georeferenced with their correspondent coordinates by the free mobile cell-GPS software application "Herramientas de GPS" v.3.1.0.5, developed by Virtual Maze ${ }^{\circledR}$ (www.virtualmaze.com). Seroprevalence was also presented by geographical information systems (GIS)-based maps. The georeferenced places were incorporated in the software Google Earth Pro ${ }^{\circledR}$, and the layers of communes, corregiments and municipalities, provided by the Open Data Pereira Geographical Information System (https://mapas-pereira.opendata.arcgis.com/), in .kml files, were included to locate the coordinate's points in the corresponding shapes. Microsoft Access ${ }^{\circledR}$ software was used to design the spatial database to import incidence rates by corregiments and communas at Pereira municipality to the GIS software. The Client GIS software open source was Kosmo Desktop 3.0 RC1® (SAIG S.L., Madrid, Spain). For access to geographic data required and sharing results with institutions, support was provided by the spatial data infrastructure for the department by the Regional Information System of the Coffee-Triangle ecoregion (SIR) as standardized and reported before [27-29]. The shapefiles of corregiments and communas (.shp) were linked to a database through spatial joined operation to produce digital maps of the seroprevalence for the study area. Data used for the GIS-based maps were derived from the geographical origin of the serosurvey at the different geographic levels [29]. 


\section{Results}

The mean age of the canine population was 4.2 years ( \pm 2.89 years, range $0.21-12.56), 53 \%$ were female, and $47 \%$ were males (Table 1 ). The average age did not differ significantly by sex (males $4.34 \pm 3.27$ years; females $4.10 \pm 2.59$ years) ( $p=0.6345)$. Other dog variables are presented in Table 1 . From the total number of canines, $89 \%$ presented clinical alterations, $100 \%$ presented anaemia, $54 \%$ lethargy, $39 \%$ alopecia, $21 \%$ decay, $21 \%$ mucocutaneous paleness, among others. 
Table 1

Physical, clinical, and living conditions of the studied dogs.

\begin{tabular}{|c|c|c|c|c|}
\hline Variable & Mean / n & $\mathrm{SD} / \%$ & Minimum & Maximum \\
\hline Age (years) & 4.20 & 2.89 & 0.21 & 12.56 \\
\hline \multicolumn{5}{|l|}{ Sex } \\
\hline Male & 53 & 53.00 & & \\
\hline Female & 47 & 47.00 & & \\
\hline Weight (kilograms) & 13.99 & 7.76 & 4.00 & 40.00 \\
\hline \multicolumn{5}{|l|}{ Body condition } \\
\hline 1 (Very slim) & 0 & 0.00 & & \\
\hline 2 (Slim) & 21 & 21.00 & & \\
\hline 3 (Ideal) & 50 & 50.00 & & \\
\hline 4 (Overweighted) & 29 & 29.00 & & \\
\hline 5 (Obese) & 0 & 0.00 & & \\
\hline Body temperature $\left({ }^{\circ} \mathrm{C}\right)$ & 38.84 & 0.96 & 30.50 & 40.00 \\
\hline Cardiac rate (beats/min) & 94.80 & 9.86 & 50.00 & 115.00 \\
\hline Respiratory rate (breaths/min) & 30.83 & 4.51 & 24.00 & 55.00 \\
\hline \multicolumn{5}{|l|}{ Capillary Refill Time (seconds) } \\
\hline 1 & 0 & 0.00 & & \\
\hline 2 & 60 & 60.00 & & \\
\hline 3 & 28 & 28.00 & & \\
\hline 4 & 10 & 10.00 & & \\
\hline 5 & 2 & 2.00 & & \\
\hline \multicolumn{5}{|l|}{ Recent deworming (last month) } \\
\hline Yes & 16 & 16.00 & & \\
\hline No & 84 & 84.00 & & \\
\hline \multicolumn{5}{|l|}{ Any vaccine (in the last year) } \\
\hline Yes & 45 & 45.00 & & \\
\hline Rabies vaccine & 43 & 43.00 & & \\
\hline No & 55 & 55.00 & & \\
\hline
\end{tabular}




\begin{tabular}{|c|c|c|c|c|}
\hline Variable & Mean / n & SD / \% & Minimum & Maximum \\
\hline \multicolumn{5}{|c|}{ Number of other dogs in the house } \\
\hline 1 & 5 & 5.00 & & \\
\hline 2 & 13 & 13.00 & & \\
\hline 3 & 12 & 12.00 & & \\
\hline$>3$ & 64 & 64.00 & & \\
\hline \multicolumn{5}{|c|}{ Number of cats in the house } \\
\hline 0 & 32 & 32.0 & & \\
\hline 1 & 16 & 16.0 & & \\
\hline 2 & 9 & 9.0 & & \\
\hline 3 & 5 & 5.0 & & \\
\hline$>3$ & 34 & 34.0 & & \\
\hline
\end{tabular}

The global seroprevalence to the selected vector-borne pathogens was $74 \%$ (95\% $\mathrm{Cl} 65-83 \%)$. The highest seroprevalence was found for E. canis/ewingii (74\%), followed by A. phagocytophilum/platys (16\%). Seropositive for Borrelia spp. and Dirofilaria spp. was $0 \%$. All the Anaplasma spp. seropositive dogs were also positive for Ehrlichia spp. (16\%).

Twenty-two percent of the houses had rudimentary walls (adobe, cardboard, and palm), $84 \%$ rudimentary roofs (wood, zinc, and palms), $41 \%$ rudimentary floors (wood and earth), and $73 \%$ of the houses had only one bathroom. In those with only one bathroom, $100 \%$ had seropositive dogs, whilst in those houses with two or more bathrooms had $65 \%(p=0.025)$. Although there was water supply $(100 \%)$ in all the houses, $28 \%$ collect and store water ( $25 \%$ in tanks and $3 \%$ in plastic recipients). The water supply in $75 \%$ was by the public system, but the rest (25\%) utilized water wells, rivers, water stream, and rainwater; $56 \%$ and reported presence of rats in the house. Thirty nine percent of the dogs, were allowed to be inside the house with the family; $10 \%$ of the dogs remain leashed in the house or the yard (all of them, $100 \%$, were seropositive), whilst $90 \%$ were free to go anywhere ( $71 \%$ were seropositive) $\left(\chi^{2}=3.903 ; p=0.048\right) ; 82 \%$ of the dogs had access to wild areas. Regarding the house waste, $81 \%$ was collected by the urban system, but the rest (29\%) is burned. Illiteracy was reported in $2 \%$ of dog owners; $8 \%$ of dog owners were unemployed at the moment of the survey. Twelve percent of owners lived in overcrowded houses $(\geq 3$ persons/room); in $70 \%$ of the owners, the number of persons per bathrooms in their houses was $\geq 3$.

The seroprevalence at rural $(79 \%)$ and urban areas $(67 \%)$ was not significantly different $(p=0.181)$. The seroprevalence was significantly higher in dogs from families of the lower socioeconomic level (I [Lowlow, the lowest], $86 \%)$, followed by level II (74\%), and III (36\%) ( $\left.X^{2}=14.162 ; p=0.001\right)$; no seropositive dogs in strata IV and V (highest) (no dogs evaluated from these level) (Fig. 3). There was high variability 
in seroprevalence by studied areas, ranging from 0\% (La Libertad Park) up to Combia, Cesar Nader, Las Brisas and Saturno $(100 \%)(p=0.033)$. In the rural areas, Cerritos was the corregiment with the highest seroprevalence (100\%), followed by Combia Baja and Caimalito (Fig. 4), whilst in the urban area, Oriente and Villasantana were the communes with the highest seroprevalence (100\%) (Fig. 4).

All the dogs with anorexia $(12 \%)$ were seropositive $(100 \%)\left(\chi^{2}=4.791 ; p=0.029\right)$. Seroprevalence was higher in those with mucocutaneous paleness $(95 \%)$ compared to those without it $(68 \%)\left(X^{2}=6.232 ; p=\right.$ $0.013)(\mathrm{OR}=9.3 ; 95 \% \mathrm{Cl} 1.18-72.9)$.

\section{Discussion}

Poverty has been linked as a determinant to multiple disease groups, especially infectious diseases [3032]. Among the infectious diseases linked to poverty, tropical diseases and vector-borne diseases, such as malaria [33-36] and dengue [37-39], have been well documented. Housing conditions are related to the occurrence and persistence of tropical infectious diseases [26, 40-43]. There is a global lack of studies exploring the links between tick-borne diseases, such as Ehrlichia spp. infection, the main pathogen that elicited antibodies in our study, and poverty.

A recent study in Argentina, assessing different infectious diseases among dogs from a rural area in the humid Chaco, found $7.9 \%$ of them prevalent for ehrlichiosis. They suggest that their findings likely reflect structural poverty, poor sanitation and lack of a safe water supply [44]. In another study, from Brazil, but in carthorses from low-income owners, authors found that $27.4 \%$ were positive for Ehrlichia exposure [45]. However, none of these studies linked the pathogen prevalence to social factors or poverty directly and statistically. In our study, we observed a social profile of the studied population, but especially a significantly higher seroprevalence among those in the poor socioeconomic level, which is at the same time related to multiple other potentially associated factors that may be suitable for tick-borne and other tropical diseases.

This study was performed in Colombia, where there is also a lack of seroprevalence studies about Ehrlichia spp. (less than 20 in PubMed database), 11 in canine populations, none in Pereira and Risaralda $[4,19,20,46-50]$. Given the high seroprevalence obtained in an area with ticks' infestation, the potential risk for zoonotic transmission to humans remains latent, deserving immediate seroprevalence studies.

Albeit their importance, emerging infectious diseases such as those caused by Ehrlichia and Anaplasma spp. are still neglected in many aspects that need to be understood, including clinical and epidemiological topics. Tick-borne diseases may lead to severe clinical consequences, both in animals and humans, leading to potential fatal outcomes [51-54]. Even for some species, there is still questioning whether these may cause, in addition, to dogs, infection in humans, such as is the case of Anaplasma platys [55]. Thus, more studies assessing their circulation in different hosts are needed to understand the ecoepidemiological associated factors, including the social ones, such as poverty [56-58]. For example, in Eastern Europe, background socioeconomic conditions determine susceptibility to risk of tick-borne 
encephalitis; some authors suggested that increased unemployment during the economic recession of 2009 triggered a sudden increase in risk [56].

Although we should acknowledge as a limitation that this study only assessed 100 dogs, preventing the possibility to run multivariate analyses, clearly evaluated multiple relevant social variables in addition to the clinical conditions of the animals, and the seroprevalence by a widely used $[8,14,59,60]$ serological diagnostic test for selected vector-borne pathogens in dogs, in different areas of the municipality, for the first also mapping, using geographical information system (GIS), the location of the assessed population, but particularly the distribution of the seropositive populations. Indeed, the use of GIS for mapping infectious diseases is highly valuable and previously used in our setting for human and animal diseases, such as malaria, Zika, neosporosis, among others [23, 27-29]. Its use, as shown here, would be helpful also in ehrlichiosis. These maps clearly showed the high seroprevalence in rural and poor communes in the urban area. The individual assessed conditions suggested that poverty is highly associated with these tick-borne pathogens in Pereira, as observed in this study.

\section{Conclusions}

Given the high seroprevalence obtained in an area with documented presence of ticks, there is a potential risk for zoonotic transmission to humans. Further seroprevalence studies in humans are needed to assess the prevalence of infections. Poverty is highly associated with these tick-borne pathogens in Pereira, as shown in the present study.

\section{Declarations}

\section{Ethics approval and consent to participate}

All persons gave their informed consent before their inclusion in the study. According to standard protocols and guidelines from the Animal Ethics Committee (CICUA) at the Fundación Universitaria Autónoma de las Américas, Colombia, animal procedures were performed according to standard protocols and guidelines. The CICUA approved and endorsed this study (Acta No. 27 de 2019).

\section{Consent for publication}

All persons gave their informed consent before their inclusion in the study.

\section{Availability of data and materials}

Available upon reasonable request.

\section{Competing interests}

None. 


\section{Funding}

This study has been funded by Fundación Universitaria Autónoma de las Américas (UAM) (Schools of Veterinary Medicine and Zootechnics, and Medicine, Pereira), Universidad Nacional Autónoma de Honduras (Faculty of Medical Sciences), Sci-Help, Vitalcare, IPS Cardiológica Eduardo Ramírez and Centro de Diagnóstico Especializado Testmol, RECEPA, and the family Trejos-Mendoza. The current article processing charges were funded by the Dirección de Investigación Científica, Humanística y Tecnológica (2-05-01-01), National Autonomous University of Honduras, Tegucigalpa, MDC, Honduras, Central America.

\section{Authors' contributions}

DKBA conceived the investigation and supervised the field and laboratory work and data analyses.

JPMA, MARM, AETM, SPV, LVM, LFMA, DON, MCP and EG, performed field and laboratory work; LVGC and AJRM revised and analyzed the clinical records of the patients and supervised laboratory work. SPV, AJRM and DKBA prepared the database with laboratory results and clinical data. AJRM and DKBA analyzed the data and wrote the firsts draft of the manuscript. All authors revised and approved the final version.

\section{Acknowledgements}

Semillero de Investigación en Zoonosis of the UAM. Also, to Diana Marcela Rojas Gallardo and Amparo Juliet Vanegas Quiceno, from the Laboratories of UAM. This study was previously presented in part at the American Society for Microbiology (ASM) \& the Federation of European Microbiological Societies (FEMS) World Microbe Forum, June 20-24, 2021 (iPoster \#6498). This study was part of the undergraduate thesis for Veterinary Medicine and Zootechnics (DVM) of JP Martínez-Arboleda, MA Reina-Mora, AE TrejosMendoza, S Pérez-Vargas, L Valencia-Mejía, LF Marín-Arboleda, D Osorio-Navia, and M Chacón-Peña, under the supervision of DK Bonilla-Aldana.

\section{References}

1. Alkishe A, Raghavan RK, Peterson AT. Likely Geographic Distributional Shifts among Medically Important Tick Species and Tick-Associated Diseases under Climate Change in North America: A Review. Insects 2021, 12(3).

2. Karim S, Kumar D, Budachetri K. Recent advances in understanding tick and rickettsiae interactions. Parasite Immunol. 2021;43(5):e12830.

3. Negi T, Kandari LS, Arunachalam K. Update on prevalence and distribution pattern of tick-borne diseases among humans in India: a review. Parasitol Res. 2021;120(5):1523-39.

4. Bonilla-Aldana DK, Quintero-Rada K, Montoya-Posada JP, Soler-Tovar D, Barato P, Arteaga-Livias K, Zambrano LI, Faccini-Martínez ÁA, Rodriguez-Morales AJ. Bovine Ehrlichiosis Prevalence: A Systematic Review and Meta-Analysis of Molecular Studies. World's Vet J. 2021;11(1):01-15. 
5. Bonilla-Aldana DK, Pomares-Cantillo LH, Beltran-Sanchez CA, Bettin-Martinez AC, Campo-Urbina ML, Rodriguez-Morales AJ, Perez-Doria A. Molecular detection of Anaplasma spp. in domestics dogs from urban areas of Soledad, Atlantico, Colombia. Infez Med. 2020;28(3):373-83.

6. Rodriguez-Morales AJ, Bonilla-Aldana DK, Idarraga-Bedoya SE, Garcia-Bustos JJ, Cardona-Ospina JA, Faccini-Martinez AA: Epidemiology of zoonotic tick-borne diseases in Latin America: Are we just seeing the tip of the iceberg? F1000Res 2018, 7:1988.

7. Rodriguez-Morales AJ, Bonilla-Aldana DK, Escalera-Antezana JP, Alvarado-Arnez LE: Research on Babesia: A bibliometric assessment of a neglected tick-borne parasite. F1000Res 2018, 7:1987.

8. Petruccelli A, Ferrara G, lovane G, Schettini R, Ciarcia R, Caputo V, Pompameo M, Pagnini U, Montagnaro S. Seroprevalence of Ehrlichia spp., Anaplasma spp., Borrelia burgdorferi sensu lato, and Dirofilaria immitis in Stray Dogs, from 2016 to 2019, in Southern Italy. Animals (Basel) 2020, 11(1).

9. Bayles BR, Allan BF. Social-ecological factors determine spatial variation in human incidence of tickborne ehrlichiosis. Epidemiol Infect. 2014;142(9):1911-24.

10. Peretti-Watel P, Ward J, Lutaud R, Seror V. Lyme disease: Insight from social sciences. Med Mal Infect. 2019;49(2):133-9.

11. Walker AR. Eradication and control of livestock ticks: biological, economic and social perspectives. Parasitology. 2011;138(8):945-59.

12. Baneth G, Nachum-Biala Y, Birkenheuer AJ, Schreeg ME, Prince H, Florin-Christensen M, Schnittger L, Aroch I. A new piroplasmid species infecting dogs: morphological and molecular characterization and pathogeny of Babesia negevi n. sp. Parasit Vectors. 2020;13(1):130.

13. Hernandez-Velasco A, Sanchez-Montes S, Romero-Salas D, Cruz-Romero A, Jimenez-Hernandez JA, Becker I, Aguilar-Dominguez M, de Leon AP. First record of natural infection with Anaplasma marginale in sucking lice infesting the water buffalo (Bubalus bubalis) in Mexico. Parasitol Res. 2020;119(11):3853-6.

14. Mendes-de-Almeida F, Alves LC, do Amaral Fernandes P, de Menezes Leivas R, Labarthe N. Infection with Dirofilaria immitis and Other Infections in Cats and Dogs from Rio de Janeiro, Brazil: The Need for Prophylactic Enforcement. Acta Parasito/ 2021.

15. Polo G, Labruna MB, Ferreira F. Satellite Hyperspectral Imagery to Support Tick-Borne Infectious Diseases Surveillance. PLoS One. 2015;10(11):e0143736.

16. Robles A, Fong J, Cervantes J. [Borrelia Infection in Latin America]. Rev Invest Clin. 2018;70(4):15863.

17. Wisely SM, Glass GE. Advancing the Science of Tick and Tick-Borne Disease Surveillance in the United States. Insects 2019, 10(10).

18. Jaimes-Duenez J, Triana-Chavez O, Mejia-Jaramillo AM. Genetic, host and environmental factors associated with a high prevalence of Anaplasma marginale. Ticks Tick Borne Dis. 2018;9(5):128695. 
19. Miranda J, Mattar S. Molecular detection of Anaplasma sp. and Ehrlichia sp. in ticks collected in domestical animals, Colombia. Trop Biomed. 2015;32(4):726-35.

20. Pesapane R, Foley J, Thomas R, Castro LR. Molecular detection and characterization of Anaplasma platys and Ehrlichia canis in dogs from northern Colombia. Vet Microbiol. 2019;233:184-9.

21. Santodomingo A, Sierra-Orozco K, Cotes-Perdomo A, Castro LR. Molecular detection of Rickettsia spp., Anaplasma platys and Theileria equi in ticks collected from horses in Tayrona National Park, Colombia. Exp Appl Acarol. 2019;77(3):411-23.

22. Vargas-Hernandez G, Andre MR, Cendales DM, Sousa KC, Goncalves LR, Rondelli MC, Machado RZ, Tinucci-Costa M. Molecular detection of Anaplasma species in dogs in Colombia. Rev Bras Parasitol Vet. 2016;25(4):459-64.

23. Rodriguez-Morales AJ, Orrego-Acevedo CA, Zambrano-Munoz Y, Garcia-Folleco FJ, Herrera-Giraldo AC, Lozada-Riascos CO. Mapping malaria in municipalities of the Coffee Triangle region of Colombia using Geographic Information Systems (GIS). J Infect Public Health. 2015;8(6):603-11.

24. Chandrashekar R, Mainville CA, Beall MJ, O'Connor T, Eberts MD, Alleman AR, Gaunt SD, Breitschwerdt EB. Performance of a commercially available in-clinic ELISA for the detection of antibodies against Anaplasma phagocytophilum, Ehrlichia canis, and Borrelia burgdorferi and Dirofilaria immitis antigen in dogs. Am J Vet Res. 2010;71(12):1443-50.

25. Stillman BA, Monn M, Liu J, Thatcher B, Foster P, Andrews B, Little S, Eberts M, Breitschwerdt EB, Beall MJ, et al. Performance of a commercially available in-clinic ELISA for detection of antibodies against Anaplasma phagocytophilum, Anaplasma platys, Borrelia burgdorferi, Ehrlichia canis, and Ehrlichia ewingii and Dirofilaria immitis antigen in dogs. J Am Vet Med Assoc. 2014;245(1):80-6.

26. Quintero K, Duran C, Duri D, Medina F, Garcia J, Hidalgo G, Nakal S, Echeverria-Ortega M, Albano C, Incani RN, et al. Household social determinants of ascariasis and trichuriasis in North Central Venezuela. Int Health. 2012;4(2):103-10.

27. Bonilla-Aldana DK, Bonilla-Aldana JL, Garcia-Bustos JJ, Lozada CO, Rodriguez-Morales AJ. Geographical trends of chikungunya and Zika in the Colombian Amazonian gateway department, Caqueta, 2015-2018 - Implications for public health and travel medicine. Travel Med Infect Dis. 2020;35:101481.

28. Rodriguez-Morales AJ, Ruiz P, Tabares J, Ossa CA, Yepes-Echeverry MC, Ramirez-Jaramillo V, Galindo-Marquez ML, Garcia-Loaiza CJ, Sabogal-Roman JA, Parra-Valencia E, et al. Mapping the ecoepidemiology of Zika virus infection in urban and rural areas of Pereira, Risaralda, Colombia, 2015-2016: Implications for public health and travel medicine. Travel Med Infect Dis. 2017;18:5766.

29. Idarraga-Bedoya SE, Alvarez-Chica J, Bonilla-Aldana DK, Moore DP, Rodriguez-Morales AJ:

Seroprevalence of Neospora caninum infection in cattle from Pereira, Colombia (small star, filled). Vet Parasitol Reg Stud Reports 2020, 22:100469.

30. Bukhman G, Mocumbi AO, Atun R, Becker AE, Bhutta Z, Binagwaho A, Clinton C, Coates MM, Dain K, Ezzati $\mathrm{M}$, et al. The Lancet NCDI Poverty Commission: bridging a gap in universal health coverage for 
the poorest billion. Lancet. 2020;396(10256):991-1044.

31. The Lancet Child. Adolescent $\mathrm{H}$. Tackling the multidimensionality of child poverty. Lancet Child Adolesc Health 2019, 3(4):199.

32. Hummel C, Knaul FM, Touchton M, Guachalla VXV, Nelson-Nunez J, Boulding C. Poverty, precarious work, and the COVID-19 pandemic: lessons from Bolivia. Lancet Glob Health. 2021;9(5):e579-81.

33. Bi Y, Tong S. Poverty and malaria in the Yunnan province, China. Infect Dis Poverty. 2014;3:32.

34. Tusting LS, Rek J, Arinaitwe E, Staedke SG, Kamya MR, Cano J, Bottomley C, Johnston D, Dorsey G, Lindsay SW, et al. Why is malaria associated with poverty? Findings from a cohort study in rural Uganda. Infect Dis Poverty. 2016;5(1):78.

35. Ricci F. Social implications of malaria and their relationships with poverty. Mediterr J Hematol Infect Dis. 2012;4(1):e2012048.

36. Santos-Vega M, Bouma MJ, Kohli V, Pascual M. Population Density, Climate Variables and Poverty Synergistically Structure Spatial Risk in Urban Malaria in India. PLoS Negl Trop Dis. 2016;10(12):e0005155.

37. Bonifay T, Douine M, Bonnefoy C, Hurpeau B, Nacher M, Djossou F, Epelboin L. Poverty and Arbovirus Outbreaks: When Chikungunya Virus Hits More Precarious Populations Than Dengue Virus in French Guiana. Open Forum Infect Dis. 2017;4(4):ofx247.

38. Mulligan K, Dixon J, Sinn CL, Elliott SJ. Is dengue a disease of poverty? A systematic review. Pathog Glob Health. 2015;109(1):10-8.

39. Bavia L, Melanda FN, de Arruda TB, Mosimann ALP, Silveira GF, Aoki MN, Kuczera D, Sarzi ML, Junior WLC, Conchon-Costa I, et al. Epidemiological study on dengue in southern Brazil under the perspective of climate and poverty. Sci Rep. 2020;10(1):2127.

40. Snyman K, Mwangwa F, Bigira V, Kapisi J, Clark TD, Osterbauer B, Greenhouse B, Sturrock H, Gosling $\mathrm{R}$, Liu J, et al. Poor housing construction associated with increased malaria incidence in a cohort of young Ugandan children. Am J Trop Med Hyg. 2015;92(6):1207-13.

41. Pham-Duc P, Nguyen-Viet H, Hattendorf J, Zinsstag J, Phung-Dac C, Zurbrugg C, Odermatt P. Ascaris lumbricoides and Trichuris trichiura infections associated with wastewater and human excreta use in agriculture in Vietnam. Parasitol Int. 2013;62(2):172-80.

42. Ercumen A, Benjamin-Chung J, Arnold BF, Lin A, Hubbard AE, Stewart C, Rahman Z, Parvez SM, Unicomb L, Rahman $\mathrm{M}$, et al. Effects of water, sanitation, handwashing and nutritional interventions on soil-transmitted helminth infections in young children: A cluster-randomized controlled trial in rural Bangladesh. PLoS Negl Trop Dis. 2019;13(5):e0007323.

43. Cardona-Arias JA. [Social determinants of intestinal parasitism, malnutrition, and anemia: systematic review]. Rev Panam Salud Publica. 2018;41:e143.

44. Enriquez GF, Macchiaverna NP, Argibay HD, Lopez Arias L, Farber M, Gurtler RE, Cardinal MV, Garbossa G. Polyparasitism and zoonotic parasites in dogs from a rural area of the Argentine Chaco. Vet Parasitol Reg Stud Reports. 2019;16:100287. 
45. Vieira TS, Vieira RF, Krawczak FS, Soares HS, Guimaraes AM, Barros-Filho IR, Marcondes M, Labruna MB, Biondo AW, Vidotto O. Ehrlichia sp. infection in carthorses of low-income owners, Southern Brazil. Comp Immunol Microbiol Infect Dis. 2016;48:1-5.

46. Arroyave E, Rodas-Gonzalez JD, Zhang X, Labruna MB, Gonzalez MS, Fernandez-Silva JA, McBride JW. Ehrlichia canis TRP36 diversity in naturally infected-dogs from an urban area of Colombia. Ticks Tick Borne Dis. 2020;11(3):101367.

47. Forero-Becerra E, Patel J, Martinez-Diaz HC, Betancourt-Ruiz P, Benavides E, Duran S, Olaya ML, Bolanos E, Hidalgo M, McBride JW. Seroprevalence and Genotypic Analysis of Ehrlichia canis Infection in Dogs and Humans in Cauca, Colombia. Am J Trop Med Hyg 2021.

48. Hidalgo M, Vesga JF, Lizarazo D, Valbuena G. A survey of antibodies against Rickettsia rickettsii and Ehrlichia chafeensis in domestic animals from a rural area of Colombia. Am J Trop Med Hyg. 2009;80(6):1029-30.

49. McCown ME, Monterroso VH, Cardona W. Surveillance for Ehrlichia canis, Anaplasma phagocytophilum, Borrelia burgdorferi, and Dirofilaria immitis in Dogs From Three Cities in Colombia. J Spec Oper Med. 2014;14(1):86-90.

50. Vargas-Hernandez G, Andre MR, Faria JL, Munhoz TD, Hernandez-Rodriguez M, Machado RZ, Tinucci-Costa M. Molecular and serological detection of Ehrlichia canis and Babesia vogeli in dogs in Colombia. Vet Parasitol. 2012;186(3-4):254-60.

51. Hardalo CJ, Quagliarello V, Dumler JS. Human granulocytic ehrlichiosis in Connecticut: report of a fatal case. Clin Infect Dis. 1995;21(4):910-4.

52. Jahangir A, Kolbert C, Edwards W, Mitchell P, Dumler JS, Persing DH. Fatal pancarditis associated with human granulocytic ehrlichiosis in a 44-year-old man. Clin Infect Dis. 1998;27(6):1424-7.

53. Paddock CD, Suchard DP, Grumbach KL, Hadley WK, Kerschmann RL, Abbey NW, Dawson JE, Anderson BE, Sims KG, Dumler JS, et al. Brief report: fatal seronegative ehrlichiosis in a patient with HIV infection. N Engl J Med. 1993;329(16):1164-7.

54. Tsiodras S, Spanakis N, Spanakos G, Pervanidou D, Georgakopoulou T, Campos E, Petra T, Kanellopoulos P, Georgiadis G, Antalis E, et al. Fatal human anaplasmosis associated with macrophage activation syndrome in Greece and the Public Health response. J Infect Public Health. 2017;10(6):819-23.

55. Arraga-Alvarado CM, Qurollo BA, Parra OC, Berrueta MA, Hegarty BC, Breitschwerdt EB. Case report: Molecular evidence of Anaplasma platys infection in two women from Venezuela. Am J Trop Med Hyg. 2014;91(6):1161-5.

56. Godfrey ER, Randolph SE. Economic downturn results in tick-borne disease upsurge. Parasit Vectors. 2011;4:35.

57. Randolph SE. To what extent has climate change contributed to the recent epidemiology of tickborne diseases? Vet Parasitol. 2010;167(2-4):92-4.

58. Sumilo D, Bormane A, Asokliene L, Vasilenko V, Golovljova I, Avsic-Zupanc T, Hubalek Z, Randolph SE. Socioeconomic factors in the differential upsurge of tick-borne encephalitis in Central and 
Eastern Europe. Rev Med Virol. 2008;18(2):81-95.

59. Kotwa JD, Jardine CM, Pearl DL, Berke O, Mercer NJ, Peregrine AS. Evaluation of the SNAP(R) 4Dx(R) plus test for the detection of Dirofilaria immitis antigen and characterization of exposure to tickborne pathogens in wild canids in southern Ontario. Vet Parasitol. 2020;283:109176.

60. Selim A, Alanazi AD, Sazmand A, Otranto D. Seroprevalence and associated risk factors for vectorborne pathogens in dogs from Egypt. Parasit Vectors. 2021;14(1):175.

\section{Figures}
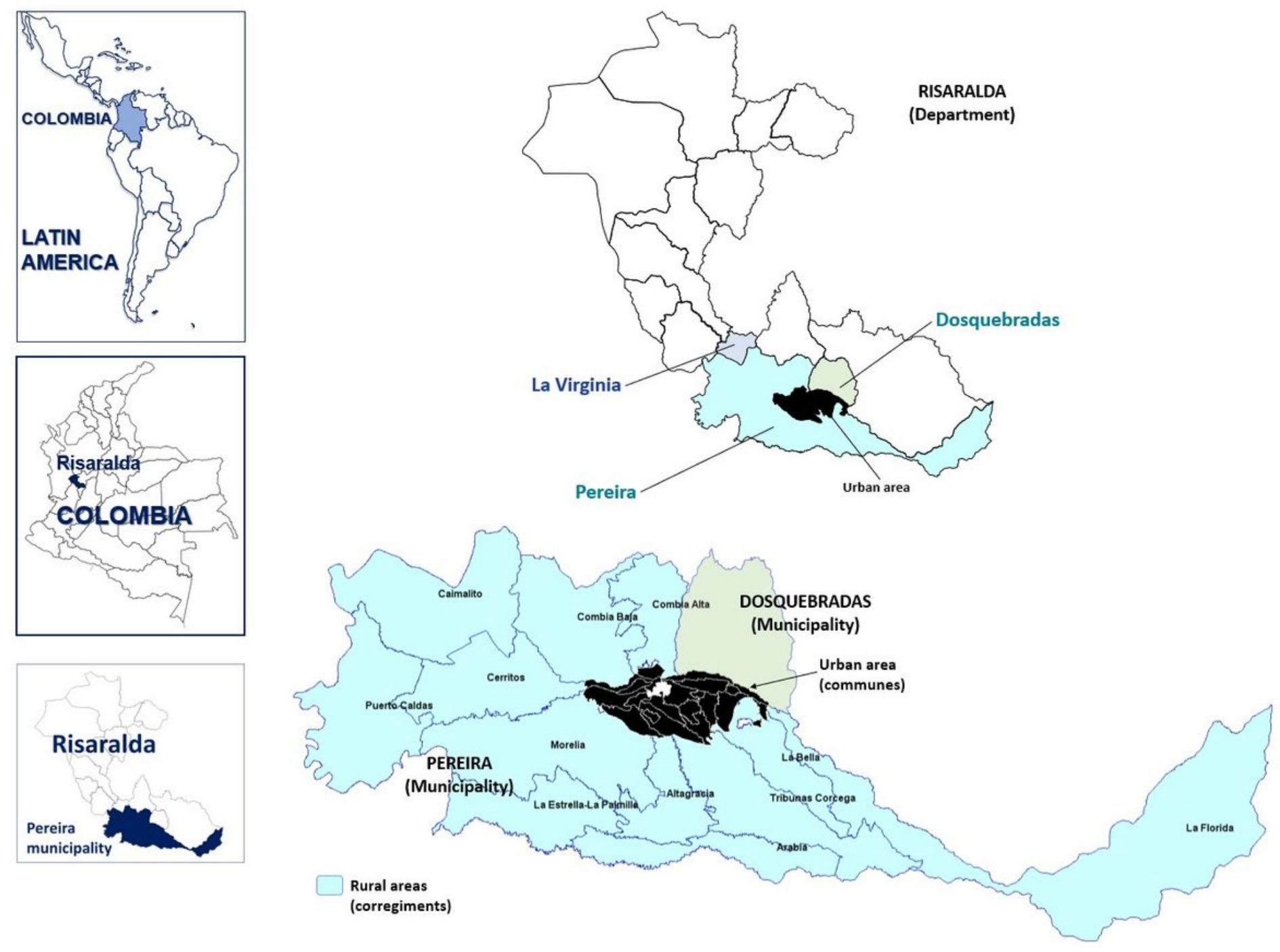

\section{Figure 1}

Relative location of Pereira and Dosquebradas municipalities, in the Risaralda department, Colombia, Latin America. Note: The designations employed and the presentation of the material on this map do not imply the expression of any opinion whatsoever on the part of Research Square concerning the legal 
status of any country, territory, city or area or of its authorities, or concerning the delimitation of its frontiers or boundaries. This map has been provided by the authors.
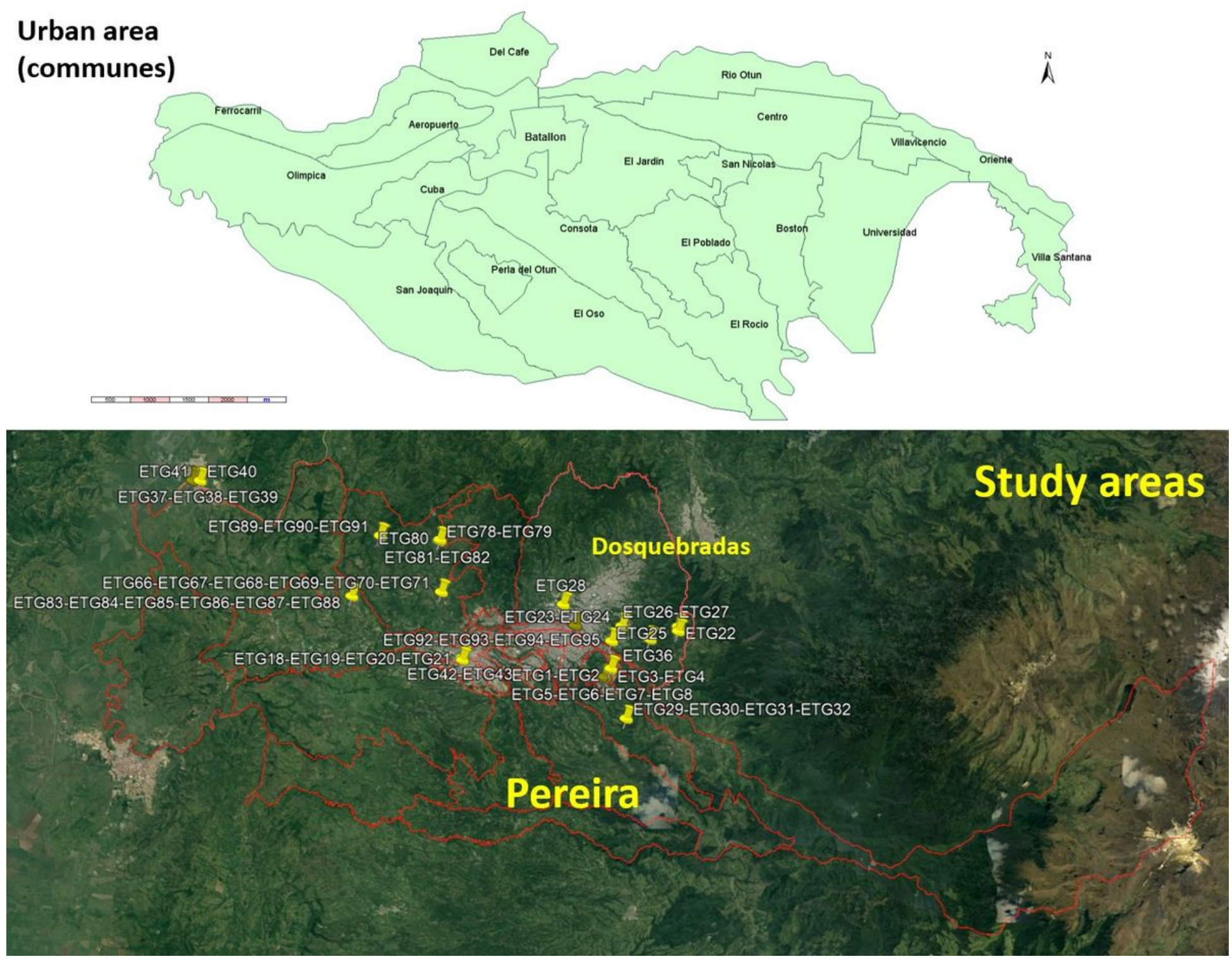

\section{Figure 2}

Urban areas (communes) of Pereira and the study areas in the metropolitan area (Pereira and Dosquebradas municipalities. Note: The designations employed and the presentation of the material on this map do not imply the expression of any opinion whatsoever on the part of Research Square concerning the legal status of any country, territory, city or area or of its authorities, or concerning the delimitation of its frontiers or boundaries. This map has been provided by the authors. 


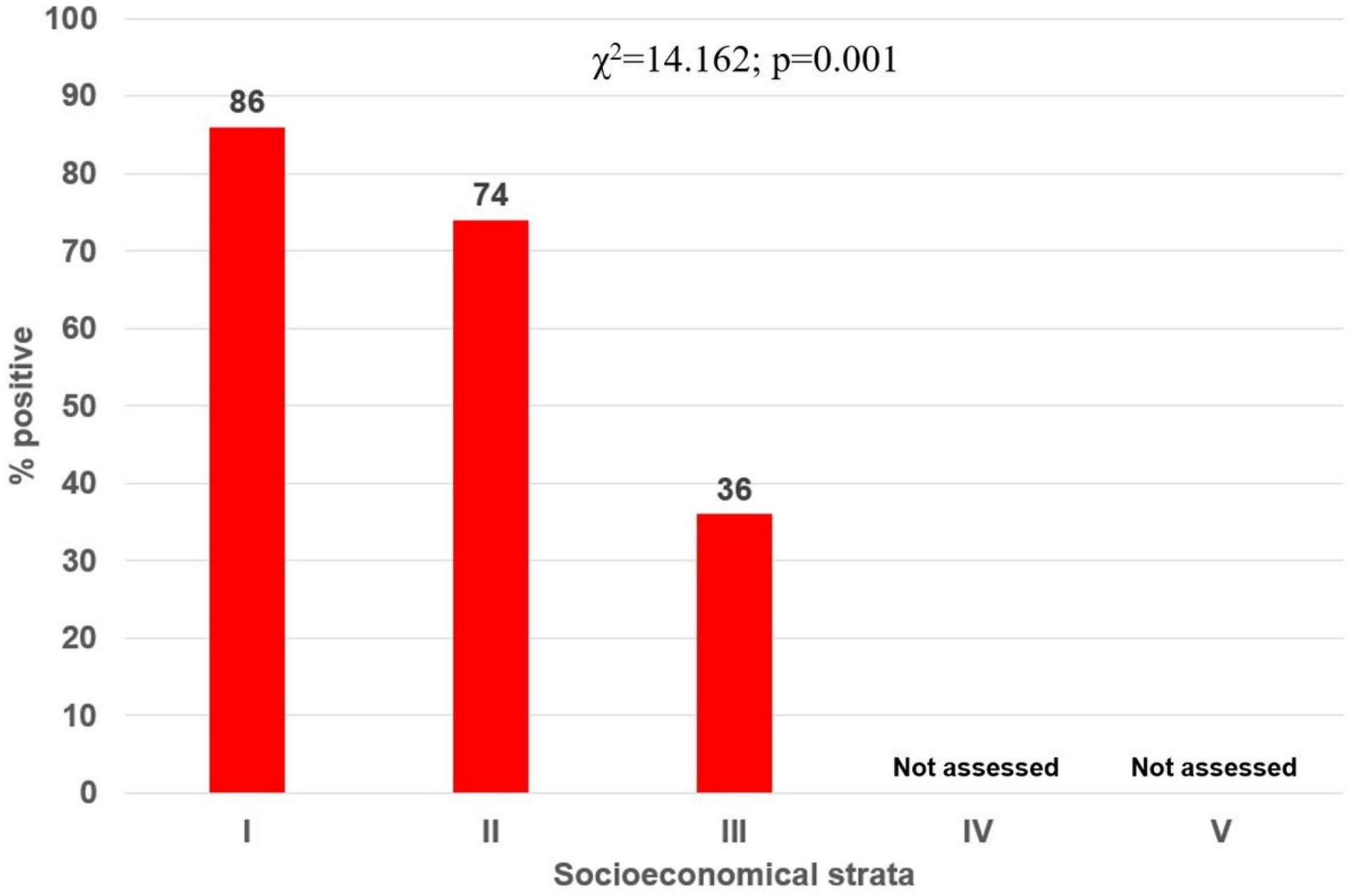

Figure 3

Seroprevalence by socioeconomic strata. 

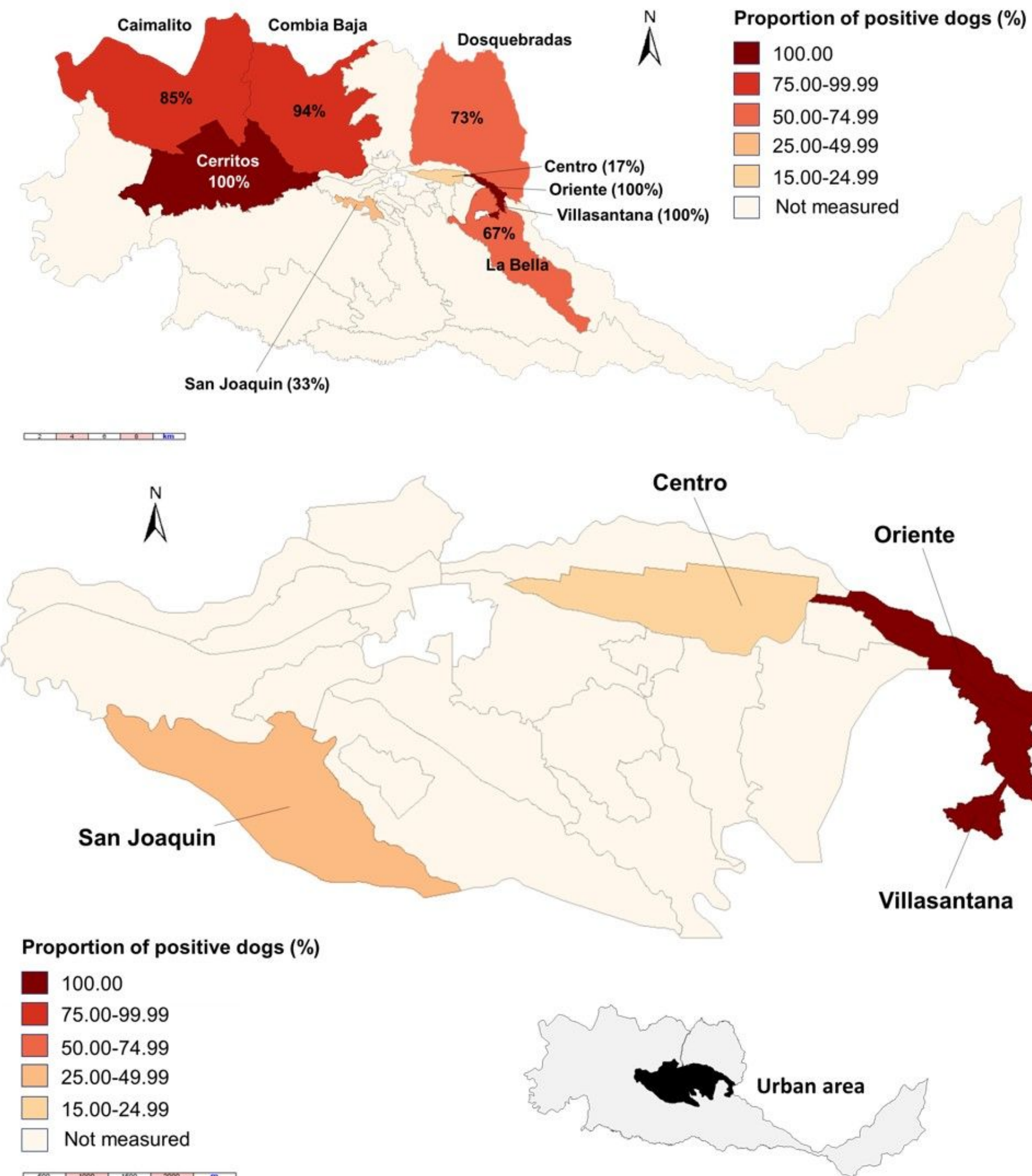

\section{Figure 4}

Seroprevalence in the municipalities of Pereira and Dosquebradas, metropolitan area, rural and urban areas of the capital of Risaralda. Note: The designations employed and the presentation of the material on this map do not imply the expression of any opinion whatsoever on the part of Research Square concerning the legal status of any country, territory, city or area or of its authorities, or concerning the delimitation of its frontiers or boundaries. This map has been provided by the authors. 